\title{
Viability of Distributed Generation in Single Family Houses Using Solid Oxide Fuel Cells in Tropical Climate
}

\author{
Siong Lee Koh
}

\begin{abstract}
The solid oxide fuel cell (SOFC) was adopted in a tri-generation configuration in this study to meet the electricity, cooling and hot water demand in a single family house in Malaysia. With the current advancement of technologies, the fuel cells can achieve a high electrical efficiency of $60 \%$. They are able to consume natural gas directly. Hence, it is more environmental friendly and fuel efficient compared to the less efficient gas turbine power plants. Furthermore, the exhaust heat energy from the high operating temperature could be harnessed to power the air-conditioners using the ejector cooling system, suitable for applications in the tropical climate. From this study, it was found that SOFC could meet the electricity, cooling and hot water demand in a single family house, with many technical and environmental merits. However, it is economically not viable with the current pricing conditions. The financial viability could be mended with higher electricity price or lower equipment costs. This might be achieved through established energy policy tools or through further development and improvement of the technology.
\end{abstract}

Index Terms-Distributed generation, solid oxide fuel cell, energy storage, thermal powered air-conditioning system, tropics.

\section{INTRODUCTION}

In early 1900s, Svante Arrhenius had already found that the earth surface temperature could increase by 5 to $6{ }^{\circ} \mathrm{C}$ if the $\mathrm{CO}_{2}$ concentration doubled [1]. More than one hundred years later, the world is still grappling with mitigating climate change caused by excessive greenhouse gas (GHG) emission from human activities. In the latest IPCC (Intergovernmental Panel on Climate Change) report, the climate change science has confirmed again with $95 \%$ certainty that global warming over the last century is mainly caused by human activity. The global average temperature has increased by $0.85^{\circ} \mathrm{C}$ over the period from 1880 to 2012. Despite the recent focus effort of the world on low carbon technologies and processes, the anthropogenic climate change is a reality now and the adverse effects are set to intensify in the coming years. It is projected in the report that, with the best measures in place, human activities will emit $990 \mathrm{GtCO}_{2}$ into the atmosphere from 2012 to 2100 . This will result in a further temperature rises of $2{ }^{\circ} \mathrm{C}$ [2]. Hence, every single known option in emission reduction must be explored and exploited. In addition, more advanced technologies need to be developed. These mitigation efforts must be undertaken by everyone from both the developed and developing countries.

Manuscript received June 25, 2014; revised August 22, 2014.

S. L. Koh is with the School of Engineering and Physical Sciences, Heriot Watt University, Putrajaya, 62100 Malaysia (e-mail: S.Koh@hw.ac.uk).
As a developing country, Malaysia is committed to play its part in emission reduction. The country has committed to reduce the national carbon emission intensity by $40 \%$, benchmarked against the 2005 level. The government has implemented various initiates towards this objective. In 2010, Malaysian Green Technology Corporation (GreenTech) was tasked by the government to spearhead the country's National Green Technology Policy. It carries the mandate to catalyst the deployment of green technologies with the objective to minimise the impact of human activities to the natural environment and resources. Low GHG emission is among its key objectives. Flagship programmes to reduce GHG emission have been introduced across all sectors, including electric transportation, green building, green government procurement and sustainable living [3].

In the energy sector, the emphasis is placed on renewable energy (RE). In the National Renewable Energy \& Action Plan, the government has set a target to increase the share of RE capacity from $1 \%$ in 2011 to $10 \%$ in 2020 [4]. The identified indigenous RE sources include biomass, biogas, mini-hydro, solar PV and solid waste. Feed-in Tariff (FiT) was identified to be the key instrument in achieving the target. Subsequently, the Sustainable Energy Development Authority of Malaysia was established in 2011 to be the implementing body of FiT.

Among all the initiatives, there is a glaring absence of one prominent technology-fuel cells. Fuel cell is able to generate electricity from hydrogen or hydrocarbons with zero or low GHG emission. The efficiency is being continuously increased with various emerging fuel cell technologies. Fuel cell systems can be deployed in various application including portable devices, stationary installation and transportation system. In 2013, more than $200 \mathrm{MW}$ of fuel cell systems were shipped. This represents a 30\% growth from the previous year [5]. Hence, the merit of this technology in Malaysian application deserves a detailed investigation. In this paper, the viability of a fuel cell application in single Malaysian homes was studied from the technological, economic, and environmental perspectives.

\section{LITERATURE REVIEW}

The fuel cell technology exists for more than 100 years. Fig. 1 shows how a fuel cell works. A fuel cell generates electricity using hydrogen and oxygen through the oxidization and reduction process. The outputs from the fuel cell are heat and water and it has zero GHG emission. Hence, it is envisaged that a hydrogen economy can be created based on this technology to replace the current fossil fuel based economy to reduce GHG emission. 


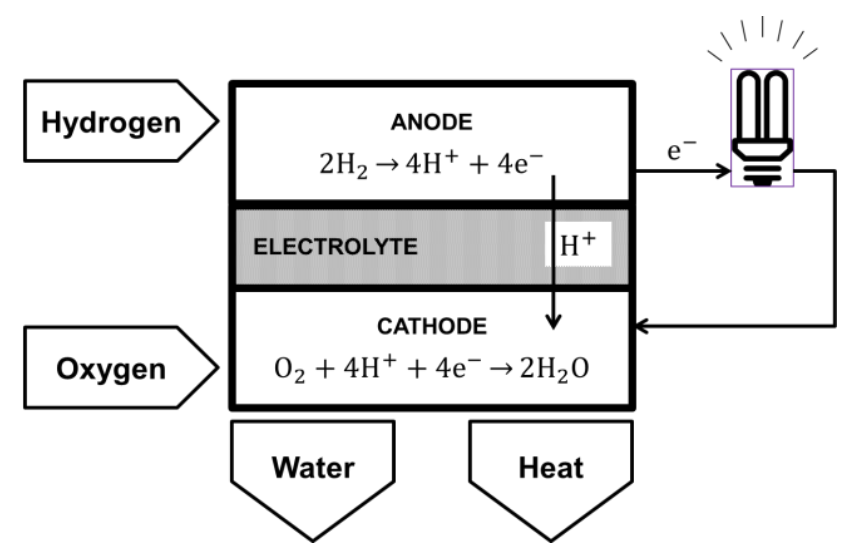

Fig. 1. Block diagram of a polymer electrolyte membrane fuel cell.

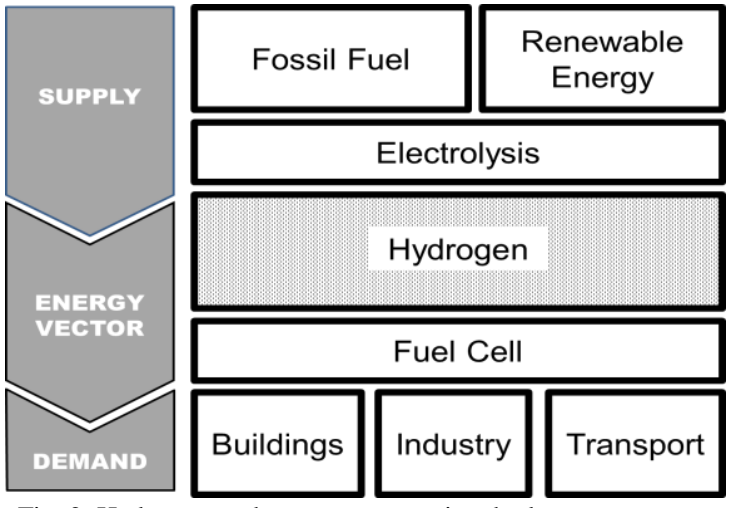

Fig. 2. Hydrogen as the energy vector in a hydrogen economy.

In a hydrogen economy depicted in Fig. 2, hydrogen plays the centre role as the energy vector of energy flow. All sources of energy supply are converted into hydrogen through the electrolysis process. The hydrogen can then be stored or distributed to the point of energy consumption. A uniform energy source in the form of hydrogen can meet the energy demand in all sectors. With the hydrogen also acting as the energy storage medium, the problems associated with the intermittent nature of renewable energy sources can be overcome.

However, there are challenges with this newly conceived hydrogen economy. These key challenges include:

1) Safety: Hydrogen is combustible. Storing and distributing large amount of hydrogen to meet all our energy needs are a potential hazard.

2) Supply: Hydrogen does not exist by itself with abundant quantity in nature. Therefore, we need to build up sufficient hydrogen production capacity, storage reserve and distribution infrastructure before we can depend on it to power all human activities.

3) Low density: The density of hydrogen is very low. Even stored under high pressure, hydrogen has a much larger volume compared to fossil fuel with the equal amount of energy. This limits its viability in some applications such as transportation.

4) Storage: The chemical property of hydrogen results in hydrogen embrittlement on the storage container. The problem is further complicated by the necessity to store it under extremely high pressure.

5) Efficiency: The overall efficiency of a hydrogen energy system shown in Fig. 2 is less than $25 \%$. The overall efficiency takes into consideration the efficiency of electricity generation from the primary energy, efficiency of electrolysis, and efficiency of fuel cell. While the efficiency of the electrolysis process could be close to $100 \%$ [6], the efficiency of conventional electricity generation from primary energy and the electricity efficiency of fuel cell are typically less than 50\% [7], [8].

6) Clean hydrogen source: If the hydrogen were to be generated from conventional fossil fuels, the low round trip efficiency will increase the emission factor and hence increase GHG emission. In order to achieve the aim of GHG emission reduction conceived in a hydrogen economy, hydrogen must be generated using clean energy sources with zero or low GHG emission. It is a challenge to harness large amount of such clean energy sources to meet the energy demand of the world.

The above challenges can be averted with the advancement of fuel cell technologies where hydrocarbon fuels could be consumed directly in a fuel cell instead of hydrogen.

TABLE I: CHARACTERISTICS OF DIFFERENT TYPES OF FuEL CELLS [5], [9],

\begin{tabular}{lllll}
\hline \hline $\begin{array}{l}\text { Fuel } \\
\text { cell } \\
\text { type }\end{array}$ & Fuel & $\begin{array}{l}\text { Electrical } \\
\text { efficiency } \\
(\%)\end{array}$ & $\begin{array}{l}\text { CHP } \\
\text { efficiency } \\
(\%)\end{array}$ & $\begin{array}{l}\text { Operating } \\
\text { Temperatur } \\
\text { e }\left({ }^{\circ} \mathrm{C}\right)\end{array}$ \\
\hline AFC & $\mathrm{H}_{2}$ & $45-60$ & $>80$ & $<100$ \\
DCFC & Carbon & $>80$ & $>90$ & $650-900$ \\
MCFC & $\mathrm{H}_{2}, \mathrm{CO}, \mathrm{CH}_{4}$ & $45-55$ & $>80$ & 650 \\
PAFC & $\mathrm{H}_{2}$ & $40-45$ & $>80$ & $200-215$ \\
PEMFC & $\mathrm{H}_{2}$ & $40-45$ & $>80$ & $<100$ \\
SOFC & $\mathrm{H}_{2}, \mathrm{CO}, \mathrm{CH}_{4}$ & $40-65$ & $>80$ & $700-1000$ \\
\hline \hline
\end{tabular}

$\overline{\bar{a} \text { Alkaline fuel cell (AFC); Direct carbon fuel cell (DCFC); Molten carbonate }}$ fuel cell (MCFC); Phosphoric acid fuel cell (PAFC); Proton exchange membrane fuel cell (PEMFC); Solid oxide fuel cell (SOFC).

Table I presents the common fuel cell technologies currently available. Among them, molten carbonate fuel cell (MCFC) and solid oxide fuel cell (SOFC) are able to consume hydrogen, carbon monoxide and methane, which are the main composition of natural gas, directly without external reformers. Hence, natural gas can be used directly. Among the two technologies, SOFC has higher electricity efficiency and it was chosen for the subsequent study in this paper.

The chemical reaction of a fuel cell produces electricity as well as heat energy. Therefore, for maximum efficiency, a fuel cell system is typical configured for combined heat and power (CHP) generation. The CHP configuration is suitable for application in the climate countries where heating contributes to a large proportion of energy consumption. In tropical countries like Malaysia, heating is not required. The utilization of the heat energy from the fuel cell is limited and this reduces the overall efficiency. In previously published works on fuel cells in Malaysia, Mahlia and Chan had limited the usage of heat for producing hot water [11]. Since the study, SOFC which has a high operating temperature above $700{ }^{\circ} \mathrm{C}$, has emerged as a promising product for distributed generation. The higher operating temperature of such fuel cells results in high quality heat energy. At higher temperature, the exhaust heat energy can be harnessed more effectively for higher value application, such as air-conditioning systems with heat absorption chiller. [8]. Furthermore, with the advancement of current fuel cell technologies, electricity efficiency has 
increased tremendously. The manufacturers are claiming an electricity efficiency of $50-60 \%$ for SOFC. This is more efficient than large scale gas power plants. Hence, fuel cells become an attractive option for power generation. Hence, fuel cells can potentially be an effective option for Malaysia in CHP where the heat energy can be harnessed to drive air-conditioner for cooling.

Malaysia has rich reserve of natural gas resources. Currently, natural gas contributes to $58 \%$ of total electricity generated in the country [12]. In addition, there is an extensive piped gas distribution network with $1791 \mathrm{~km}$ of pipeline serving more than 10000 residential users in West Malaysia [13]. This existing infrastructure will be able to support the immediate deployment of SOFC system in the major cities to meet the increasing electricity demand in a sustainable way.

\section{METHODOLOGY}

\section{A. Technological Analysis}

In this study, a SOFC system was configured in a tri-generation configuration to meet the energy demand of a single family house for electricity, cooling and hot water system as shown in Fig. 3.

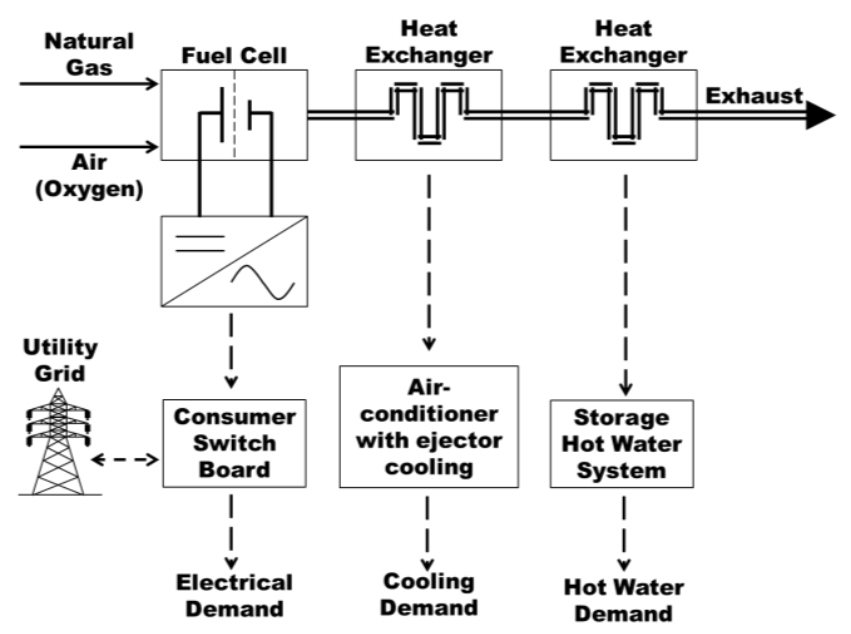

Fig. 3. Grid connected SOFC for a single family house in tri-generation configuration.

The operating temperature of SOFC is above $700{ }^{\circ} \mathrm{C}$. At this high temperature, the exhaust heat is of high quality that can be harnessed to drive the air-conditioning system, as shown in Fig. 3. Chen and Ni [8] have previously studied a tri-generation system with similar configuration for hotel application. In their studied, they have selected heat absorption chiller for the air-conditioning system to cater for the large cooling load. For a single family house application in this study, however, chiller based air-conditioning is not suitable due to the smaller cooling load. Air cooled split unit air-conditioning system is commonly used for this type of application. To reduce the electricity consumption of such air-conditioning system by using heat as the supplementary energy source, Huang et al. [14], [15] had proposed to include an ejector cooling system (ECS) in parallel with air cooled air-conditioner to meet the cooling demand. Using solar collector as the energy source for the generator in their study, it was found that the electricity consumption of the air-conditioner was reduced by an average $50 \%$. Instead of solar thermal energy, the exhaust heat from the SOFC was tapped to drive the generator of the ECS in this study. This would overcome a major limitations identified in the research of Huang et al. whereby the variability of solar radiation affected the efficiency of the proposed system. Unlike the solar radiation, the exhaust heat from the SOFC could provide a constant energy source to the generator of the ECS.

Downstream to the air-conditioner, the remaining heat in the exhaust was utilised to produce hot water to meet the requirement of the household.

In this proposed configuration, the overall electrical efficiency of the SOFC system as defined in (1) could be maximized. In the equation, $\eta_{\text {overall }}$ is the overall electrical efficiency, $E_{\text {elec }}$ the electricity output $(\mathrm{kWh}), E_{a c}{ }^{\prime}$ the energy saved from the air-conditioner $(\mathrm{kWh}), E_{h w}$ heat energy from the fuel cell utilised for producing hot water $(\mathrm{kWh})$, and $F I$ the fuel input $(\mathrm{kWh})$.

$$
\eta_{\text {overall }}=\left(E_{\text {elec }}+E_{a c}{ }^{\prime}+E_{h w}\right) / F I
$$

With respect to the operating scheme, continuous full power capacity output scheme was selected. As the SOFC requires high starting energy and a high operating temperature, other load following operating schemes are not suitable [16]. Based on this selected operating scheme, a net metering configuration was adopted for connection to the power grid. As the SOFC was configured to operate at full output capacity, the excess electricity could be exported to the power grid when the SOFC output exceeded the electricity demand of the household. Similarly, additional electricity could be imported from the power grid when the demand exceeded the output of the SOFC. As the excess electricity generated could be exported to the grid, the SOFC system was not sized according to the electricity demand. Instead, it was sized based on the cooling demand of the household. In the tropical climate of Malaysia, the electrical, cooling, and hot water demand of a household remain almost constant throughout the year. Hence, a single daily demand profile was assumed in this study to represent the demand throughout the year.

Based on the selected capacity and operating scheme of the SOFC, the available exhaust heat was harnessed to power the ECS. The input temperature of ECS was set to $100{ }^{\circ} \mathrm{C}$, as discussed in previously published works [14]. Further downstream, the remaining heat was used to produce hot water system. The working temperature of the hot water system was set at $60{ }^{\circ} \mathrm{C}$.

\section{B. Economic Analysis}

In the economic analysis, the costs for the SOFC system and the ECS system were included in the capital costs computation. However, the costs of the air-conditioner and the hot water system were not included as it was assumed that the cost would have been expended even without the SOFC.

For the operation costs, the natural gas fuel cost and operation and maintenance $(\mathrm{O} \& \mathrm{M})$ costs were included. The O\&M costs were calculated based on $5 \%$ of the total capital cost per annum. 
The revenue was calculated based on the cost of the total electricity generated as well as the electricity saved from the air-conditioner and hot water system. The prevailing electricity rate was adopted as currently, FiT did not include fuel cell technologies.

The payback period was then calculated based on $80 \%$ plant factor, $3 \%$ inflation rate and $6 \%$ interest rate.

\section{Environmental Analysis}

The environmental analysis focused mainly on the GHG emission reduction. The total emission avoided was computed based on the difference between the average emission factor of the power industry in Malaysia and the effective emission factor of the SOFC system in this study, as defined in (2):

$$
E F_{\text {eff }}=E F_{f c} \times P_{\text {elec }} /\left(P_{\text {elec }}+P_{a c}{ }^{\prime}+P_{h w}\right)
$$

where $E F_{\text {eff }}$ is the effective emission factor $\left(\mathrm{kg} \mathrm{CO}_{2} / \mathrm{kWh}\right)$; and $E F_{f c}$ is the emission rate of the fuel cell based on electricity output $\left(\mathrm{kgCO}_{2} / \mathrm{kWh}\right)$.

The fuel saving in natural gas was also computed based on the higher efficiency of the fuel cell compared to that of the existing natural gas power plant.

\section{CAlculation}

\section{A. Technological Analysis}

Table II presents the average daily electricity usage in a typical Malaysia home [11].

TABLE II: DAILY ELECTRICITY CONSUMPTION IN A TYPICAL MALAYSIAN HOME

\begin{tabular}{ll}
\hline \hline Type of load & Consumption $(\mathrm{kWh})$ \\
\hline Water heater & 1.68 \\
Air-conditioner & 2.52 \\
Lighting, small power & 7.81 \\
TOTAL & 12.01 \\
\hline \hline
\end{tabular}

The capacity of the SOFC was sized up based on the air-conditioner demand. At a typical COP (coefficient of performance) of 3.85 for modern air-conditioner [14], 2.52 $\mathrm{kWh}$ of electricity consumption is corresponding to a daily cooling load of $9.7 \mathrm{kWh}$. The heat energy required to meet this cooling load using ECS would be higher as an ECS typically has a lower COP. At a COP of 0.3 , the amount of heat energy required is $32.34 \mathrm{kWh}$. It was found in the previously published works [15] that an average of $50 \%$ cooling load can be met using ECS. To achieve this $50 \%$ target, the total input heat energy required to the ECS would be $16.17 \mathrm{kWh}$ per day. The technically extractable exhaust heat energy for ECS consumption $\left(E_{\text {ecs }}\right)$ was then computed using (3). $E_{x h}$ denotes the total energy within the exhaust heat. $T_{\text {exl }}$ denotes the exhaust air temperature from the fuel cell, which was assumed to be $500{ }^{\circ} \mathrm{C}$ in this study. $T_{e x 2}$ denotes the temperature of the working fluid for ECS, which was $100^{\circ} \mathrm{C}$. $\eta h x$ denotes the efficiency of the heat exchanger which was assumed to be $90 \%$. With $E_{e c s}=16.17 \mathrm{kWh}, E_{x h}$ was found to be $22.46 \mathrm{kWh}$ per day, which is equivalent to $0.94 \mathrm{~kW}$.

$$
E_{e c s}=E_{x h} \times \eta_{h x} \times\left(T_{e x 1}-T_{e x 2}\right) / T_{e x 1}
$$

At $60 \%$ electrical efficiency and $90 \%$ CHP efficiency, $E_{x h}$ represents $30 \%$ of the input power. Hence, the selected SOFC would have a primary energy input power of $3.13 \mathrm{~kW}$ which was translated to an electrical output capacity of $1.88 \mathrm{~kW}$. Hence, the electrical rated capacity of the SOFC was selected to be $2 \mathrm{~kW}$. Operating at full rated capacity continuously, the SOFC would generate $48 \mathrm{kWh}$ per day. The required natural gas fuel input in a day is $80 \mathrm{kWh}$ or $0.2728 \mathrm{mmBtu}$. With the selected capacity, $50 \%$ of the air-conditioner electricity consumption could be saved. This is equivalent to $1.26 \mathrm{kWh}$ per day.

The total electricity generated exceeded the daily demand of the household. The excess electricity generated would be exported to the power grid through the incomer supply feeder. In Malaysia, the minimum incomer feeder for domestic consumer is rated at $60 \mathrm{~A} 230 \mathrm{~V}$ single phase, which is able to transmit up to $12 \mathrm{~kW}$ of electrical power. Hence, it is more than sufficient for exporting $2 \mathrm{~kW}$ of electricity generated from the SOFC without any additional upgrading works.

Downstream to the ECS, the available energy from the exhaust heat $\left(E_{h w}\right)$ for producing hot water was calculated using (3). $T_{e x 3}$ denotes the temperature of the hot water system, which is $60{ }^{\circ} \mathrm{C}$. Hence, $E_{h w}$ was found to be $2.26 \mathrm{kWh}$. This is more than the average consumption of $1.68 \mathrm{kWh}$ in Table II.

$$
E_{h w}=\left(E_{x h}-E_{e c s}\right) \times \eta_{h x} \times\left(T_{e x 2}-T_{e x 3}\right) / T_{e x 2}
$$

With $E_{\text {elec }}=48 \mathrm{kWh}, E_{a c}{ }^{\prime}=1.26 \mathrm{kWh}, E_{h w}=1.68 \mathrm{kWh}$, and $F I=80 \mathrm{kWh}$, the overall electrical efficiency of the SOFC system was found to be $64 \%$ using (1).

\section{B. Economic Analysis}

In this analysis, the total capital cost and operation cost were computed as in Table III whereas the projected revenue in Table IV.

From the above calculation, it was found that the revenue of USD 1651 was lower than the operating cost of USD 2432. Therefore, the project would suffer a loss and the investment was not economically sustainable, based on the prevailing pricing condition.

TABLE III: CAPITAL AND OPERATION COST OF THE SOFC SYSTEM IN TRIGEN CONFIGURATION

\begin{tabular}{lrr}
\hline \hline Description & $\begin{array}{c}\text { Capital Cost } \\
(\text { USD) }\end{array}$ & $\begin{array}{c}\text { Operation Cost } \\
(\text { USD) }\end{array}$ \\
\hline 2 kW SOFC & $13500^{\mathrm{b}}$ & - \\
ECS System (1RT) & $3900^{\mathrm{c}}$ & - \\
Annual fuel cost $^{\mathrm{d}}$ & - & 518 \\
Annual O\&M $^{\mathrm{e}}$ & - & 870 \\
Interest $^{\mathrm{f}}$ & - & 1044 \\
TOTAL $^{\mathrm{a}}$ & 17400 & 2432 \\
\hline
\end{tabular}

${ }^{\mathrm{a}}$ Based on exchange rate of USD $1=$ RM 3.

${ }^{\mathrm{b}}$ Quotation obtained from Ceramic Fuel Cells Limited (Australia).

${ }^{\mathrm{c}}$ Price estimated by Huang et al. [15].

${ }^{\mathrm{d}}$ Total natural gas fuel cost computed based on $0.2728 \mathrm{mmBtu}$ per day at USD 6.51 (RM 19.52) per mmBtu as per the current gas tariff in Malaysia [17] with $80 \%$ plant factor.

e $5 \%$ of the total capital cost per annum.

${ }^{\mathrm{f}} 6 \%$ of the total capital cost per annum. 
TABLE IV: ANNUAL REVENUE / COST SAVED FROM ELECTRICITY OF THE SOFC SYSTEM IN TRIGEN CONFIGURATION

\begin{tabular}{lrcr}
\hline \hline Description & \multicolumn{1}{c}{$\begin{array}{c}\text { Daily } \\
(\mathrm{kWh})\end{array}$} & $\begin{array}{c}\text { Daily } \\
(\mathrm{USD})^{\mathrm{a}}\end{array}$ & \multicolumn{1}{c}{$\begin{array}{c}\text { Annual } \\
(\mathrm{USD})^{\mathrm{b}}\end{array}$} \\
\hline Electricity generated & 48.00 & 5.3280 & 1555.78 \\
Saving (Hot water) & 1.68 & 0.1865 & 54.45 \\
Saving(air-conditioner) & 1.26 & 0.1399 & 40.84 \\
TOTAL & 50.94 & 5.6543 & 1651.07 \\
\hline \hline
\end{tabular}

${ }^{\mathrm{a}}$ Based on the prevailing domestic tariff of USD 0.111 (RM 0.334) per kWh [18].

${ }^{b}$ With a plant factor of $80 \%$.

It was further noted that the cost of the ECS system constitute a substantial portion within the capital cost, which subsequently also translated to a high O\&M cost and interest payment. Therefore, a further study was made on a modified system, omitting the ECS component to form the cogeneration configuration for electricity and hot water generation. In this configuration, the operation cost was reduced to USD 2003 and the revenue to USD 1610.23, as shown in Table $\mathrm{V}$ and Table VI respectively. The revenue is still below the operation cost and the system is also financially not viable.

\section{Environmental Analysis}

The annual GHG emission reduction based on the above system configuration was calculated as in Table VII. The GHG emission reduction at each home was $6.26 \mathrm{t} \mathrm{CO}_{2}$ per year. This is equivalent to a $57 \%$ reduction.

TABLE V: CAPITAL AND OPERATION COST OF THE SOFC SYSTEM IN COGENERATION CONFIGURATION

\begin{tabular}{lrr}
\hline \hline Description & $\begin{array}{c}\text { Capital Cost } \\
\text { (USD) }\end{array}$ & $\begin{array}{c}\text { Operation Cost } \\
\text { (USD) }\end{array}$ \\
\hline 2 kW SOFC & 13500 & - \\
ECS System (1RT) & - & 518 \\
Annual fuel cost & - & 675 \\
Annual O\&M & - & 810 \\
Interest & - & 2003 \\
TOTAL & 13500 & \\
\hline \hline
\end{tabular}

TABLE VI: ANNUAL REVENUE / COST SAVED FROM ELECTRICITY OF THE SOFC SYSTEM IN COGENERATION CONFIGURATION

\begin{tabular}{lccc}
\hline \hline Description & $\begin{array}{c}\text { Daily } \\
(\mathrm{kWh})\end{array}$ & Daily (USD) & $\begin{array}{c}\text { Annual } \\
(\mathrm{USD})\end{array}$ \\
\hline Electricity generated & 48.00 & 5.3280 & 1555.78 \\
Saving (Hot water) & 1.68 & 0.1865 & 54.45 \\
Saving(air-conditioner) & - & - & - \\
TOTAL & 49.68 & 5.5145 & 1610.23 \\
\hline \hline
\end{tabular}

TABLE VII: GHG EMISSION REDUCTION CALCULATION

\begin{tabular}{|c|c|c|c|}
\hline Quantity & $\overline{\text { Unit }}$ & SOFC & $\overline{\text { Grid }}$ \\
\hline Daily generation & $\mathrm{kWh}$ & 48.00 & 50.94 \\
\hline Daily saving & $\mathrm{kWh}$ & 2.94 & 0.00 \\
\hline Annual generation ${ }^{\mathrm{a}}$ & $\mathrm{kWh}$ & $14,016.00$ & $14,874.48$ \\
\hline Annual saving & $\mathrm{kWh}$ & 858.48 & 0.00 \\
\hline Emission factor & $\mathrm{gCO}_{2} / \mathrm{kWh}$ & $340.00^{\mathrm{b}}$ & $741.00^{\mathrm{c}}$ \\
\hline Total annual emission & $\mathrm{tCO}_{2}$ & 4.77 & 11.02 \\
\hline $\begin{array}{l}\text { GHG emission } \\
\text { reduction }\end{array}$ & $\mathrm{tCO}_{2}$ & 6.26 & \\
\hline
\end{tabular}

${ }^{\mathrm{a}}$ With $80 \%$ plant factor.

${ }^{\mathrm{b}}$ Based on product catalogue from Ceramic Fuel Cells Limited (Australia) [19].

c2012 statistics from GreenTech Malaysia [20].
In addition to GHG emission reduction, SOFC consumes less fuel due to the higher efficiency. The overall efficiency of $64 \%$ is much higher than the typical gas power plants, which have an average efficiency of $35.34 \%$ [21]. It was found that $35.67 \mathrm{mmBtu}$ of primary energy in the form of natural gas could be saved in a house every year.

\section{Discussion OF RESUlts}

From the above calculation, it was found that the SOFC system had great potential in GHG emission reduction. It was able to reduce the GHG emission by $64 \%$. By increasing the penetration rate of such system in the residential houses, the aggregated GHG emission reduction would be substantial. Based on the statistics by Malaysia Energy Commission [21], there were 7.3 million residential customers connected to the grid in 2012. With an assumed penetration rate of just $10 \%$, for example, the annual GHG emission reduction will be 4.57 million $\mathrm{t} \mathrm{CO}_{2}$. This represents $2 \%$ of total GHG emission in the country. In addition, 26 million mmBtu of natural gas would be conserved.

Technically, such system could be readily implemented with the existing connection to the grid. The system could substantially reduce the peak demand of the residential load by reducing the water heater and air-conditioner load, resulting in a more stable and efficient power system. In addition, the system would be able to cater for the increasing load from emerging demand, such as electric vehicle charging. With the existing power system, the increasing penetration rate of electric vehicles and load from charging requirement will require upgrading of the infrastructure, particularly in the distribution network. With distributed generation from the SOFC, these increased demands could be catered for locally, without the needs to upgrade the distribution system.

Despite the technical and environmental benefits, it is anticipated that the adoption rate of such system will not be high as it is financially not viable under the current pricing conditions. Further investigation was carried out to identify the price points whereby investment on such a system would be financially viable. The effect of increasing the electricity price and reducing the capital cost of the equipment was studied.

From Fig. 4, it was found that, to achieve a viable payback period of around 7 years, the price of electricity was to be increased to USD 0.29 per $\mathrm{kWh}$. Although the price is more than double the current price of USD 0.111 per $\mathrm{kWh}$, it is comparable to the fit in tariff rate for solar PV of USD 0.33.

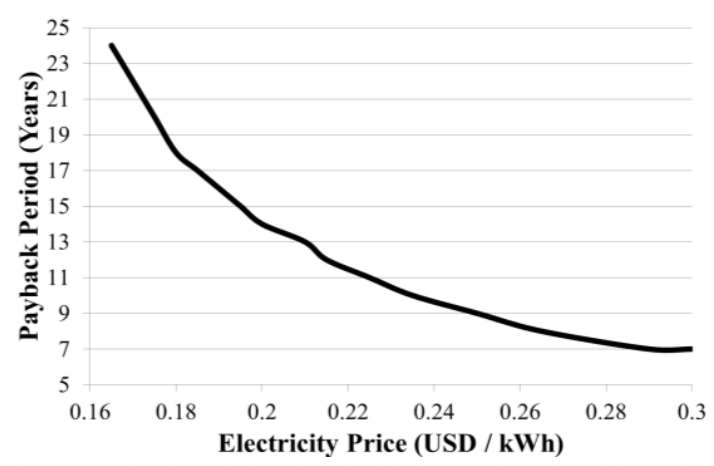

Fig. 4. Payback period reduced with increasing electricity price. 


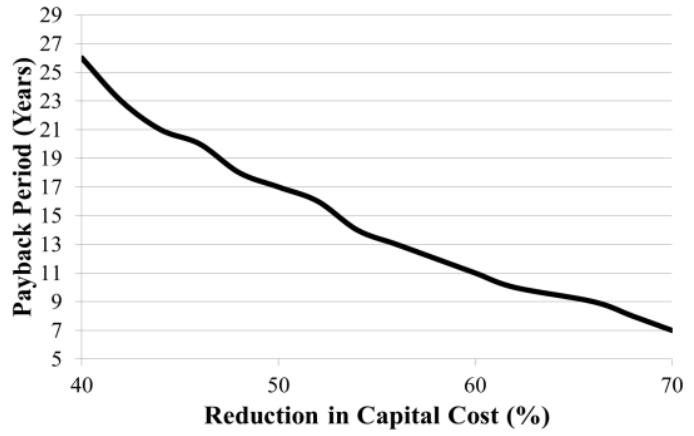

Fig. 5. Payback period reduced with reducing equipment cost.

From Fig. 5, it was found that a reduction of $70 \%$ on the equipment cost was required in order to make the investment viable with a payback period of 7 years.

\section{CONCLUSION}

In this study, the tri-generation SOFC system was found to be suitable to meet the electricity, cooling and hot water demand requirements of a single family residential building, with many technical and environmental merits. However, the investment on such a system is not economically viable with the current pricing conditions. In order to encourage the adoption of such a system, the financial viability for investing in the system has to be mended. This can be achieved by either increasing the electricity price or reducing the equipment cost The policy makers may consider using policy tools such as FiT, tax exemption, subsidy and grant to achieve these objectives. On the technology side, the equipment may be further developed and researched to improve the efficiency and reduce material cost. One potential area is the COP of the ECS. Currently, it is below 0.3, which is far from the technical limit of 1 . By doubling the COP to 0.6 , it will be able to double the cooling capacity [22].

Future research may also be carried out in energy storage system in conjunction with the application of SOFC. With the storage system, the variability of the demand may be reduced to cut down on the maximum demand to the grid and make the power system more efficient. Furthermore, excess electricity may be stored to meet the peak demand of the grid and hence command a premium price. Similarly, additional hot water storage may be included to store the excess heat energy for subsequent consumption by the ECS and hot water usage.

In addition, other renewable energy sources such as solar PVs and solar thermal collectors may be included to form a hybrid system with the SOFC. Research on the optimal sizing and control of each component may be carried out.

\section{REFERENCES}

[1] S. Arrhenius and H. Borns, Worlds in the Making: the Evolution of the Universe, Harper, 1908.

[2] IPCC, "The physical science basis. Contribution of working group I to the fifth assessment report of the intergovernmental panel on climate change," Intergovernmental Panel on Climate Change, 2013.

[3] GreenTech. (May 22, 2014). Moving Forward: Core Focus for GreenTech Malaysia. [Online]. Available: http://www.greentechmalaysia.my/content.asp?zoneid=2\&cmscategor yid=338\#.U31qiNKSySo

[4] Kettha, "National renewable energy policy \& action plan," Ministry of Energy, Green Technology and Water, Putrajaya, Malaysia, November $17,2008$.
[5] D. Carter and J. Wing, "The fuel cell industry review 2013," Fuel Cell Today, Royton, UK September 2013.

[6] M. Carmo et al., "A comprehensive review on PEM water electrolysis," Int. J. of Hyd. Energy, vol. 38, pp. 4901-4934, 2013.

[7] S. L. Koh, Y. S. Lim, and S. Morris, "Potential of advanced coal and gas combustion technologies in GHG emission reduction in developing countries from technical, environmental and economic perspective," Energy Procedia., vol. 12, pp. 878-885, 2011.

[8] J. M. P. Chen and M. Ni, "Economic analysis of a solid oxide fuel cell cogeneration/trigeneration system for hotels in Hong Kong," Energy and Buildings, vol. 75, pp. 160-169, 2014.

[9] S. Giddey et al., "A comprehensive review of direct carbon fuel cell technology," Prog. in Energy and Combu. Sci., vol. 38, pp. 360-399.

[10] C. J. Cleveland and C. Morris, Handbook of Energy. Volume I, Diagrams, Charts, and Tables, 2013.

[11] T. M. I. Mahlia et al., "Life cycle cost analysis of fuel cell based cogeneration system for residential application in Malaysia," Rene. and Sustainable Energy Reviews, vol. 15, pp. 416-426, 2011.

[12] A. M. Abdul Razak, "Safe guarding growth," Energy Malaysia, vol. 1, p. 3, 2014

[13] Energy Commission Malaysia, "Piped gas distribution industry statistics 2011," Energy Commission Malaysia, 2011.

[14] B. J. Huang et al., "Optimal control and performance test of solar-assisted cooling system," Applied Thermal Engineering, vol. 30, pp. 2243-2252, 2010.

[15] B. J. Huang et al., "System performance and economic analysis of solar-assisted cooling/heating system," Solar Energy, vol. 85, pp. 2802-2810, 2011

[16] T. Hong, D. Kim, C. Koo, and J. Kim, "Framework for establishing the optimal implementation strategy of a fuel-cell-based combined heat and power system: Focused on multi-family housing complex," Applied Energy, vol. 127, pp. 11-24, 2014.

[17] Malaysia Energy Commission. (June 22, 2014). Natural Gas Tariff for Gas Malaysia Sdn. Bhd. Customer. [Online]. Available: http://www.st.gov.my/index.php/consumer/gas/tariff.html

[18] TNB. (June 22, 2014). Tariff Rates. [Online]. Available: http://www.tnb.com.my/residential/pricing-and-tariff/tariff-rates.html

[19] BlueGen, Next Generation Electricity, 2014.

[20] Green Tech Malaysia. (June 22, 2014). Emission factor for electricity generation from 2005-2012. [Online]. Available: http://www.greentechmalaysia.my/content.asp?zoneid=4\&cmscategor yid=84\#.U6j0PpSSySo

[21] Energy Commission Malaysia, "Performance and statistical information 2012," 2012.

[22] B. J. Huang et al., "A solar ejector cooling system using refrigerant R141b," Solar Energy, vol. 64, pp. 223-226, 1998

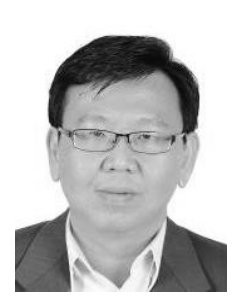

Siong Lee Koh is a graduate of Mississippi State University, USA with more than 15 years of experience working in the industry. As an electrical engineer, he has had the opportunity to involve in many development projects in the country, ranging from rural school developments in Sabah to high profile buildings in the new administration centre of Malaysia in Putrajaya. He was the electrical engineer in charge during the construction of Perbadanan Putrajaya Complex; the Parcel E Government Office Complex which houses the Ministry of Health, Ministry of Education, Ministry of Energy, Green Technology and Water; and the first smart school complex in Putrajaya which his son has subsequently attended. While on official assignments, he has travelled to the most rural part of Malaysia as well as some major cities in the world including Los Angeles, Chicago, Seoul, Perth and Riyadh.

$\mathrm{He}$ found his passion in sustainable development when he was assigned to the project to build a new office building for the Ministry of Energy, Water and Communication (now Ministry of Energy, Green Technology and Water) in Putrajaya, which is the first building designed to achieve a low energy index in Malaysia. The building is now famously known as the LEO (Low Energy Office) Building, which is widely referenced and benchmarked against in the green building industry in Malaysia. Subsequently, he pursued his interest in this area further by completing his master and PhD degrees in renewable and sustainable energy. Dr. Koh is currently an assistant professor with Heriot Watt University Malaysia, with research interest in sustainable energy.

Dr. Koh is a registered professional engineer (electrical) with Board of Engineers Malaysia, a member of the Institute of Engineers Malaysia and a registered Green Building Facilitator with Green Building Index Malaysia. 